\title{
THE EFFECT OF PROFESSIONALISM IN VILLAGE ASSET MANAGEMENT, OPTIMIZATION OF THE VILLAGE ASSETS UTILIZATION AND COMMUNITY EMPOWERMENT ON INCREASING VILLAGE ORIGINAL INCOME IN KUALA SEMPANG VILLAGE, SERI KUALA LOBAM DISTRICT, BINTAN REGENCY
}

\author{
* Mawarni ${ }^{1}$, Ngaliman ${ }^{2}$, Bambang Satriawan ${ }^{3}$, Indrayani $^{4}$ \\ Department of Management Master Program Batam University, Indonesia \\ Correspondence Address: Jl. Abdulyatama No 5, Batam, Kepulauan Riau. \\ E-mail: ${ }^{1)}$ Mawarni713@gmail.com
}

\begin{abstract}
This study aims to determine and describe how the influence of professionalism in managing village assets, optimizing the use of village assets and empowering the community so that it contributes to increasing village original income. The type of data used in this research is quantitative data. The data source in this research is secondary data. The object of this research is Kuala Sempang Village, Seri Kuala Lobam District, Bintan Regency. The results showed that the professionalism of village asset management had no significant effect on village original income, the optimization of the village assets utilization had a significant positive effect on village original income and community empowerment had no significant effect on village original income. So, in this study from the three variables only one variable has a significant positive effect on the village's original income.
\end{abstract}

Keywords: Professionalism, Optimization, Community Empowerment, Village Original Income.

\section{INTRODUCTION}

The constitution of the Republic of Indonesia Number 6 of 2014 concerning Villages brings new breakthroughs for Village Administration and village communities in building and improving the economic welfare of rural communities. One of the programs that can be carried out in accordance with the Village Law is through the management of village assets. Village assets are assets that belong to the village government which are used as well as possible for the progress and prosperity of the village community. However, the implementation is sometimes not in accordance with these aims and objectives.

Based on the Constitution of the Republic of Indonesia Number 6 of 2014 concerning Villages, Village assets are village property that originates from the village's original assets, purchased or obtained at the expense of the village income and expenditure budget or other legal acquisition. Village assets can be in the form of communal land, village markets, animal markets, boat moorings, village buildings, fish auctions, agricultural product auctions, village owned forests, village springs, public baths and other village assets. Furthermore, this asset can be managed properly to increase the village's original income so as to increase the economy in the village and towards an independent village. To achieve optimal asset utilization, management of the asset's life cycle is required. Given the importance of managing village assets, it is a must for the village government to manage village assets professionally, effectively and prioritizing economic aspects so that the economic welfare of village communities can be achieved in village assets utilization.

In Kuala Sempang Village, Seri Kuala Lobam District, Bintan Regency faces several problems related to the use of village assets and their management, for example it is still unclear the source of finance given to village assets utilization and the not yet optimal function of the BPD

International Journal of Social Science, Educational, Economics, Agriculture Research, and Technology (IJSET) 
THE EFFECT OF PROFESSIONALISM IN VILLAGE ASSET MANAGEMENT, OPTIMIZATION OF THE VILLAGE ASSETS UTILIZATION AND COMMUNITY EMPOWERMENT ON INCREASING VILLAGE ORIGINAL INCOME IN KUALA SEMPANG VILLAGE, SERI KUALA LOBAM DISTRICT, BINTAN REGENCY

DOI: https://doi.org/10.54443/ijset.v1i2.6

(Village Consultative Body) in collaboration with the Village Head. to compile Village Regulations on the utilization and management of village assets. This is stated in Constitution Number 6 of 2014 in Article 77 paragraph 3, which states that the management of assets belonging to dea is discussed by the Village Head and the Village Consultative Body based on the procedures for managing village property as regulated in a Government Regulation.

This problem becomes a problem that must be resolved so that the hope of becoming a developed and independent village can be achieved. The manifestation of village assets utilization in this case is in the form of Village-Owned Enterprises (BUMdes), the management of village wealth must be empowered and successful in order to increase village income.

Apart from managing and utilizing assets, villages must also empower their communities. Empowerment of village communities is an effort to develop independence and community welfare by increasing knowledge, attitudes, skills, behavior, abilities, awareness, and utilizing resources through the establishment of policies, programs, activities and assistance in accordance with the essence of problems and priority needs of the village community (Yabbar, 2015). This community empowerment aims to improve community capacity in village development. With this community empowerment, it is also expected to be able to increase community income as well as village income.

From the explanation above, it can be seen several problems that can be examined in this study, the first is whether the professionalism of village asset management has a significant positive effect on village original income. Professionalism is aimed at the ability of the apparatus to provide good, fair, and inclusive services and is not just a match of expertise with the place of assignment. So that the apparatus is required to have the ability and expertise to understand and translate the aspirations and needs of the community into activities and service programs (Riyanto, 2014). In this case, the professionalism of the village apparatus can fully classify the village asset management program to make it easier in terms of management and supervision.

Riyanto's (2014) research result states that bureaucratic professionalism has a significant effect on the performance of government officials. This means that with professionalism it can improve the performance of the apparatus which has implications for the village's original income. Other research based on the similarity of variables, namely from the results of research by Amrie Firmansyah (2018) states that the management of village assets has a significant effect on local government performance as seen from the increase in village original income.From this study, the hypothesis used is :

H1: Professionalism in managing village assets has a positive effect on village original income.

The second problem is whether the optimization of village assets utilization has a significant positive effect on the village's original income. Optimization is carried out to achieve maximum results, while in this study the maximum results are obtained by utilizing assets appropriately. The use of assets can be carried out in various ways, namely leasing, borrowing and using, cooperating or by building for delivery.

Ni Luh Putu Eka Widiantari (2017) indicates that the optimization of regional assets is by identifying and inventorying the value of assets and potential regional assets owned or controlled by the Regional Government of Denpasar City, so that regional assets can be controlled properly and minimize problems that arise due to assets. unrecorded and improper use of assets. 
Management of village assets utilization is not just mere administration, but how to increase efficiency and effectiveness and create added value in managing assets so that assets can be managed optimally, asset value is the largest component of all wealth owned by the village. Apart from that, assets are also one of the problems that commonly occur in village governments, therefore asset management must be carried out optimally and adhere to existing regulations.

Ibnu Khamdun1, Sukomo 2, Dendy Syaiful Akbar3 (2019) indicate that the main obstacle that occurs is the optimization of the use of village assets to increase the original village. Village as regulated in Permendagri No.1 of 2016 concerning Village Asset Management Article 28 which states that the use of village assets is determined in order to support the implementation of village governance and the status of their use is determined annually by a Village Head Decree.

$\mathrm{H} 2$ : Optimizing the use of village assets affects the village's original income.

Village community empowerment is an effort to develop community independence and welfare by increasing knowledge, attitudes, skills, behavior, abilities, awareness, and utilizing resources through the establishment of policies, programs, activities, and assistance in accordance with the essence of problems and priority needs of the village community. Questions and Answers Regarding the Village Law (June 2015) The Ministry of Village answered several questions that were frequently asked about the concept of empowering rural communities.

Why is the empowerment of rural communities necessary?

Empowerment of village communities aims to enable villages to take collective action as a unit that involves various stakeholders at the village government level, village community, and other parties to encourage participation and utilize the capacity of village communities in the village development process, formulate development plans that are pro- poor., as well as increasing the capacity and quality of human resources in the village.

What are the focuses in empowering rural communities?

1. Forming the village as a complete, democratic and strong governmental society between the village government, BPD and the community.

2. Building advanced, strong and populist village leadership through regeneration.

3. Realizing the rights and obligations of village communities in village governance, village development, and community development.

4. Encourage community participation in every stage of development planning and implementation, improve the quality and capacity of human resources, ensure that village development policies and programs are pro-poor, and provide assistance to rural communities in a sustainable manner in accordance with local priorities, potentials and wisdom.

H3: Community empowerment affects the village's original income.

This research is expected to have benefits for interested parties, especially the Kuala Sempang village government, Seri Kuala Lobam District, Bintan Regency. The benefits of research are theoretical benefits, namely that this research is expected to provide additional knowledge and references on the management of village assets, utilization of village assets and community empowerment that affect the increase in village original income. The second benefit is that the practicality of this research is expected to make a concrete contribution to the village government in increasing the village's original income.

\section{IMPLEMENTATION METHOD}

This research was conducted in Kuala Sempang Village, Seri Kuala Lobam District, Bintan Regency, where the research was conducted to analyze the effect of Village Asset Management 
THE EFFECT OF PROFESSIONALISM IN VILLAGE ASSET MANAGEMENT, OPTIMIZATION OF THE VILLAGE ASSETS UTILIZATION AND COMMUNITY EMPOWERMENT ON INCREASING VILLAGE ORIGINAL INCOME IN KUALA SEMPANG VILLAGE, SERI KUALA LOBAM DISTRICT, BINTAN REGENCY

DOI: https://doi.org/10.54443/ijset.v1i2.6

Professionalism, Optimization of Village Asset Utilization and Community Empowerment on Increasing Village Original Income.

The type of data used in this research is quantitative data. Quantitative data is a research method based on the philosophy of positivism, used to examine specific populations or samples, data collection using research instruments, quantitative or statistical data analysis, with the aim of testing predetermined hypotheses (Sugiyono, 2017: 8). In this study, quantitative data is a value or score on the answers given by respondents to the questions in the questionnaire. The data used in this study are primary data, namely research data obtained or collected directly from the original source (without intermediaries). While the data sources in this study were obtained from answers to questionnaires distributed to respondents.

The questionnaire used in this study was measured using a 5-point liker scale using a score range of $1-5$. Respondents were asked to fill in a check mark $(\sqrt{ })$ on the answer that is considered correct on each question item. The scoring used in measuring the questionnaire answers is:

1. Strongly Disagree (STT) with a score interval of 1

2. Disagree (TS) with a score interval of 2

3. Neutral $(\mathrm{N})$ with a score interval of 3

4. Agree (S) with a score interval of 4

5. Strongly Agree with a score interval of 5

The questionnaire consists of four parts, namely: the first variable of professionalism in the management of village assets which consists of 10 question items, the second part is the variable of optimizing village assets utilization which consists of 15 question items, the third part is the variable of community empowerment which consists of 13 question items, and the part that the four variables of village original income consisting of 8 question items.

Population is a generalization area consisting of objects / subjects that have certain qualities and characteristics set by researchers to study and then draw conclusions (Sugiyono, 2017: 80). The population in this study was Kuala Sempang Village, Seri Kuala Lobam District, Bintan Regency which has been calculated using the Slovin formula.

The data analysis method used in this research is validity and reliability test, classical assumption test, hypothesis test. Data analysis was processed using the help of the SPSS Versi20 program

\section{RESULTS AND DISCUSSION}

Based on the results of the validity test for the professionalism variable in the management of village assets, it can be seen that the 10 question items have a correlated item-total correlation value greater than the r-table value $(0.23)$. This means that the indicators used to measure the variable professionalism of village asset management can be said to be valid as a measuring tool. Second, the results of the validity test for the optimization variable for village assets utilization can be seen that of the 15 question items, the correlated item-total correlation value is greater than the r-table value (0.23). This means that the indicators used to measure the variable of optimizing village assets utilization can be said to be valid as a measuring tool. Third, the results of the validity test for the community empowerment variable can be explained that the 13 question items have a 
correlated item- total correlation value greater than the $r$-table value $(0.23)$. This means that the indicators used to measure community empowerment can be said to be valid as a measuring tool.

Based on the results of the reliability test of the variable professionalism of village asset management which shows that the Combach's Alpha value is 0.858 and the results of the validity test for the village's original income variable, it can be seen that of the 6 question items, the correlated item-total correlation value is greater than the r-table value $(0,23)$. This means that the indicators used to measure the village's original income variable can be said to be valid as a measuring tool.

Table 1. Normality Test Results

\begin{tabular}{ccc}
\hline One-Sample Kolmogorov- & \multicolumn{2}{c}{ Unstandardized Residual } \\
Smirnov Test & & 5 \\
$\mathrm{~N}$ & Mean & 0,000000 \\
& Std. Deviation & 2,77169545 \\
& Absolute & 0,136 \\
Normal Parameters & Positive & 0,068 \\
& Negative & $-0,136$ \\
& & 0,974 \\
Kolmogorov-Smirnov Z & & 0,299 \\
Asymp. Sig. (2-tailed) & \\
\hline
\end{tabular}

In Table 1, the results of the data normality test using the Kolmogiorov-Smirnov statistic show that the Asymp value. Sig. (2-tailed) is greater than 0.05 . This shows that the data distribution is normally distributed.

Visually, the graphical image of the normal probability plot can be seen in Figure 1 below:

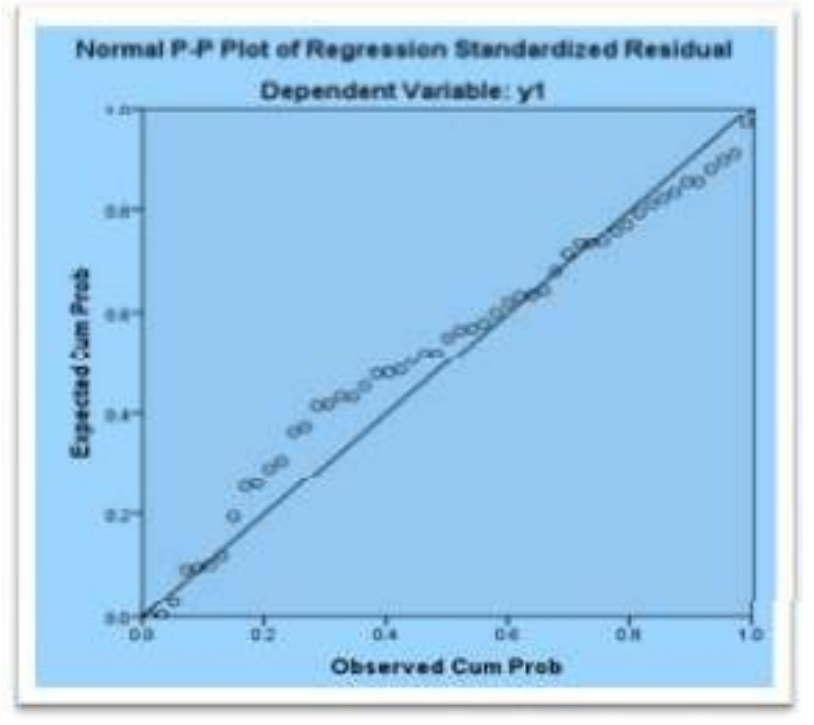

Based on Figure 1 above, it shows that the regression model obtained is normally distributed. Where the data distribution is around the diagonal line, this means the normality test is fulfilled. 
THE EFFECT OF PROFESSIONALISM IN VILLAGE ASSET MANAGEMENT, OPTIMIZATION OF THE VILLAGE ASSETS UTILIZATION AND COMMUNITY EMPOWERMENT ON INCREASING VILLAGE ORIGINAL INCOME IN KUALA SEMPANG VILLAGE, SERI KUALA LOBAM DISTRICT, BINTAN REGENCY

DOI: https://doi.org/10.54443/ijset.v1i2.6

The results of the Heteroscedasticity Test can be presented in Figure 2 below:

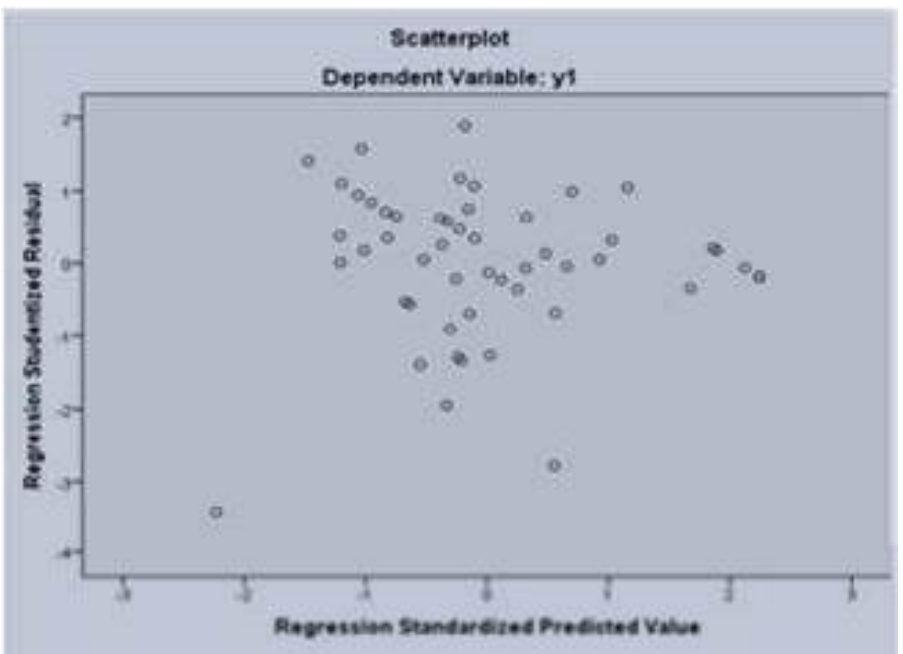

Figure 2 Heteroscedasticity Test Results

The test results in Figure 2 show that the scaterplot graph does not form a certain pattern, such as wavy, widened or narrowed, so it can be concluded that the regression model does not contain heteroscedasticity or can be called homoscedasticity.

The result of the multicolonearity test is that the Tolerance value of each variable of professionalism in village asset management is greater than $10 \%$ or 0.1 , namely for the variable of professionalism in village asset management of 0.297 , the variable of optimizing village assets utilization is 0.407 and the variable of community empowerment is 0.299 . Likewise, the VIF of each variable has a value smaller than 10, namely for the professionalism variable of village asset management of 3.365, the variable of optimizing the use of village assets by 2.457 and the variable for community empowerment of 3.349. From these results it can be concluded that there is no relationship or multicollinearity symptom between the independent variables.

Hypothesis testing is done by determining the coefficient of determination, multiple linear regression, the $t$ model feasibility test and the f model feasibility test.

First, the coefficient of determination test is used to determine the amount in percent of the effect of the independent variable as a whole on the independent variable. The small value of R2 means the ability of the independent variables to explain the variation in the dependent variable very limited. Based on the results of the determination test, it is known that the value of Adjusted R Square is 0.464 , which means that $46 \%$ of the variation in the magnitude of Audit Quality Reduction can be explained by variations in independent variables, namely the professionalism of village asset management, optimization of village asset utilization, and community empowerment. While the remaining $56 \%$ is explained by other variables outside the model.

Multiple linear regression analysis aims to determine the effect of professionalism in managing village assets, optimizing village assets utilization, and community empowerment on village original income in villages located in Tabanan Regency, Bali. Multiple regression analysis can be presented in Table 2 below : 


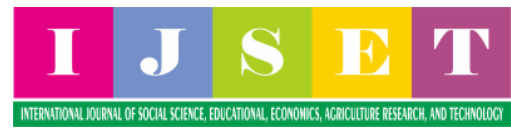

Table 2

Results of Multiple Linear Regression Analysis

\begin{tabular}{|c|c|c|c|c|c|c|}
\hline \multirow[t]{2}{*}{ Model } & \multicolumn{3}{|c|}{$\begin{array}{l}\text { Unstandardized } \\
\text { Coefficients }\end{array}$} & \multicolumn{2}{|c|}{$\begin{array}{c}\text { Standardized } \\
\text { Coefficients } \\
\mathrm{t} \\
\text { Beta }\end{array}$} & \multirow[t]{2}{*}{ Sig. } \\
\hline & & & & Error & & \\
\hline 1 (Constants) & -10.286 & 5.177 & & & -1.987 & .053 \\
\hline $\begin{array}{c}\text { Profesionalism of Village } \\
\text { Assets Management }\end{array}$ & .239 & .183 & & .248 & 1.306 & .198 \\
\hline $\begin{array}{c}\text { Optimization of Village Assets } \\
\text { Utilization }\end{array}$ & .334 & .124 & & .438 & 2.701 & .010 \\
\hline Community Empowerment & .058 & .149 & & .074 & .389 & .699 \\
\hline
\end{tabular}

Based on the results of the analysis above, it can be seen that the constant $(\alpha)=-10.286$, the regression coefficient $b 1=0.239$, the coefficient value $b 2=0.334$, and the coefficient value $b 3=0.058$. Based on these results, the multiple linear regression equation can be determined the pattern of influence of the variable professionalism of village asset management (X1), optimization of village assets utilization (X2), community empowerment (X3) on village original income (Y) can be expressed by the following equation:

$\mathrm{Y}=\alpha+\mathrm{b} 1 \mathrm{X} 1+\mathrm{b} 2 \mathrm{X} 2+\mathrm{b} 3 \mathrm{X} 3+\mathrm{e}$

$\mathrm{Y}=-10,286+0,239 \mathrm{X} 1+0,334 \mathrm{X} 2+0,058 \mathrm{X} 3+\mathrm{e}$

The regression coefficient of village asset management professionalism (X1) of 0.239 illustrates that Village Asset Management Professionalism has a positive influence on the amount of Village Original Income, meaning that if the village apparatus has high Village Asset Management Professionalism it will be able to increase the village's original income. The regression coefficient of Village Asset Utilization Optimization (X2) of 0.334 illustrates that the Optimization of Village Asset Utilization has a positive effect on the amount of Village Original Income, meaning that if the village apparatus optimizes the use of Village Assets, it can increase Village Original Income. The regression coefficient for Community Empowerment (X3) is 0.058, illustrating that Community Empowerment has a positive effect on Village Original Income, meaning that if the village government carries out Community Empowerment, it can increase Village Original Income.

Based on the above equation, it can be explained that the multiple regression coefficient is positive. This means that there is a positive influence between the Professionalism of Village Asset Management (X1), Optimization of Village Asset Utilization (X2), Community Empowerment (X3) on Village Original Income (Y).

The results of the $t$ test (partial) obtained the first results: the effect of professionalism in village asset management on village original income, obtained a tcount value of $1.306<$ from a ttable value of 1.677 and a significant value of Village Asset Management Professionalism of $0.198>$ from 0.05 so $\mathrm{H} 1$ was rejected. This shows that the variable professionalism in managing village assets does not have a significant effect on village original income. Second, the effect of 
optimizing village assets utilization on the village's original income, the tcount value is $2.701>$ from the $t$ table value of 1.677 and the significant value of Village Asset Utilization Optimization is 0.010 <from 0.05 so that $\mathrm{H} 2$ is accepted. This indicates that the Village Asset Utilization Optimization variable has a positive and significant effect on village original income. And third, the effect of community empowerment on the village's original income, the tcount value is 0.0389 < from the ttable value of 1.677 and the significant value for Community Empowerment is $0.699>$ from 0.05 so that $\mathrm{H} 3$ is rejected. This has a significant effect on the village's original income.

\section{CONCLUSION}

Based on the research that has been done, it can be concluded as follows :

1. The variable of professionalism in village asset management (X1) has a tcount of $1.306<$ of the ttable value of 1.677 and a significant value of $0.198>0.05$, so it can be said that the variable professionalism of village asset management has no significant effect on village original income.

2. The variable of optimizing village assets utilization (X2) has a tcount of $2.701>$ a t table of 1.677 and a significant value of $0.010<0.05$, so it can be said that the variable of optimizing the use of village assets has a positive and significant effect on village original income.

3. The community empowerment variable (X3) has a t-count value of 0.389 <from the ttable value of 1.677 and a significant value of $0.699>0.05$, so it can be said that the community empowerment variable does not have a significant effect on the village's original income.

\section{REFERENCES}

Constitution of the Republic of Indonesia Number 6 of 2014 concerning Villages

Ilham, R. N., Sinaga, S., Putri, D. E., Sinta, I., \& Fuadi, F. (2021). EFEK DARI LEVERAGE DAN UKURAN PERUSAHAAN DALAM MEMENGARUHI TINGKAT PROFITABILITAS. JURNAL ILMIAH EDUNOMIKA, 5(02).

Lasta Irawan, A., Multazam, M. ., Nur Ilham, R. ., \& Kayacilar, C. . (2021). INFLUENCE OF PRODUCT QUALITY ON CONSUMER PURCHASE INTEREST WITH CUSTOMER SATISFACTION AS A VARIABLE INTERVENING IN BLACK ONLINE STORE MARKET LHOKSUMAWE CITY: (Case Study on Black Market Online Store Customers in Lhoksumawe City). International Journal of Social Science, Educational, Economics, Agriculture Research, and Technology (IJSET), 1(1), 1-10. https://doi.org/10.54443/ijset.v1i1.1

Regulation of the Minister of Home Affairs of the Republic of Indonesia Number 1 of 2016 concerning Village Asset Management

Regulation of the Minister of Home Affairs of the Republic of Indonesia Number 20 of 2018 concerning Village Original Income.

Republic of Indonesia Government Regulation Number 43 of 2014 concerning Implementing Regulations for Village Law.

Riinawati, R. (2021). The Development of Information Technology and Its Influence on the Field of Management Accounting. Journal of Financial and Tax, 1(2), 131-149. 
Yabbar, Rahmah and Ardi Hamzah, 2015 Village Governance: From Village Regulations to VillageOwned Enterprise Management; From Village Development Planning to Village Financial Management. Surabaya.Pustaka.

Santoso, J. T., Ginantra, N. L. W. S. R., Arifin, M., Riinawati, R., Sudrajat, D., \& Rahim, R. (2021). Comparison of Classification Data Mining C4. 5 and Naïve Bayes Algorithms of EDM Dataset.

Sugiyono. 2017.8 Educational Research Methods, Quantitative Approaches, Qualitative, and R \& D Bandung. Alfabeta.

Sugiyono. 2017.80 Population Definition Bandung. Alfabeta.

Ghozali, Imam. 2011 Multivariate Analysis Application with SPSS Program. Semarang: BP Undip. Research by Ibnu Khamdun1, Sukomo 2, Dendy Syaiful Akbar3 (2019) on optimizing the use of village assets to improve the village's original.

Ni Luh Putu Widiantari's research, 2017, Optimizing the Utilization of Regional Assets in the Context of Increasing the Regional Original Income (PAD) of Denpasar City.

Pocket Book of Questions and Answers Regarding the Law on Villages, June 2015 Ministry of Villages, Development of Disadvantaged Areas, and Transmigration of the Republic of Indonesia. 
Volume 1 Issue 2 (2022)

THE EFFECT OF PROFESSIONALISM IN VILLAGE ASSET MANAGEMENT, OPTIMIZATION OF THE VILLAGE ASSETS UTILIZATION AND COMMUNITY EMPOWERMENT ON INCREASING VILLAGE ORIGINAL INCOME IN KUALA SEMPANG VILLAGE, SERI KUALA LOBAM DISTRICT, BINTAN REGENCY

DOI: https://doi.org/10.54443/ijset.v1i2.6 